\title{
The role of intellectuals in the state-society nexus
}

AUTHOR:

lain Edwards

\section{AFFILIATION:}

${ }^{1}$ Gordon Institute of Business Science, University of Pretoria, Johannesburg, South Africa

\section{CORRESPONDENCE TO: lain Edwards}

EMAIL:

edwardsl@gibs.co.za

POSTAL ADDRESS: GIBS, PO Box 787602, Sandton 2146, South Africa

\section{KEYWORDS:}

sub-Saharan Africa; political intellectuals; liberation movements; independent states

\section{HOW TO CITE:}

Edwards I. The role of intellectuals in the state-society nexus. S Afr J Sci. 2015;111(5/6), Art. \# a0105, 2 pages. http://dx.doi. org/10.17159/sajs.2015/a0105

(c) 2015. The Author(s). Published under a Creative Commons Attribution Licence.
In the recent Mapungubwe Institute for Strategic Reflection (MISTRA) \& Lilliesleaf Roundtable held on 4 March 2015 , leading figures in the intellectual life of liberation movements in sub-Saharan Africa reflected on the past, present and future relationships of such political intellectuals within the new independent states of the region. This self-reflection offered candid and striking views:

- $\quad$ As had already happened in all other sub-Saharan African countries, the South African liberation movements had 'consumed' its own intellectuals.

- Intellectuals within the liberation movements have to accept their share of responsibility for the dire predicament which independent Africa faces.

- $\quad$ Old paradigms must be questioned.

- $\quad$ Such intellectuals must now re-imagine their role, creating appropriate distance between themselves and the state and nationalist movements now in power so as to offer dispassionate analysis and public comment on governance and leadership.

- There is a great need for new ideas, particularly in the fields of development economics, governance, management, leadership and public policy.

- The spectrum of who is within the intellectual sphere must be broadened to include business and science and technology.

The social origins of black intellectuals in sub-Saharan Africa lie in the colonial period, most particularly in the later decades of the 19th century. Originally incorporated into the colonial enterprise, they at first sought greater spaces, particularly social and political, for a wider emancipatory vision within colonialism. Soon they were using the very components of modernity on the imperial margins - like Christianity, schools, literacy and communication, primarily newspapers - to challenge the claimed superiority of the coloniser. These were the men who imagined the new national image, and laid the intellectual and expressly often political dynamics of the national liberation movements. It was hardly an accident that the first president of the African National Congress (ANC) was Dr JL Dube, the publisher of Ilanga lase Natal and a famed educationist, and that Nelson Mandela voted at Dube's Ohlange Institute in 1994.

Prompted by the current crises within the ANC and the state, and held with considerable pre-publicity, the symposium was aimed at stimulating wider debate on the role of intellectuals in contemporary society. There were three sessions. In the first session on the southern African context, the speakers were Dr lbbo Mandaza (Zimbabwe), Dr Ayanda Ntsaluba (former Director-General of International Relations) and Prof. Xolela Mangcu (University of Cape Town, UCT). In the second session on South Africa, the speakers were Mr Joel Netshitenzhe (MISRA and long-time ANC National Executive Committee member) and Prof. Ben Turok (long-serving and now retired senior ANC Member of Parliament). The final session concerned the humanities and social sciences and the 'race, class and gender' question speakers were Prof. Ari Sitas (UCT), Prof. Tshilidzi Marwala (Deputy ViceChancellor: Research and Innovation, University of Johannesburg) and Ms Nombonisa Gasa (UCT).

Throughout the sessions, common themes surfaced from both the presentations and the discussions:

- What is the real issue? That, on coming to power, independent states sidelined their intellectuals. Whilst it was always thought that southern Africa, and in particular South Africa, would be different, this has not been the case. This situation is a cause of much soul-searching amongst such intellectuals. As within the social strata of the political intelligentsia, they feel part of the ruling elite, and yet now have an ambivalent relationship to the very state they helped bring to power.

- What responsibility do intellectuals have for the crises befalling independent sub-Saharan Africa states? Here two themes were dominant. Firstly, intellectuals and their perspectives were part of the problems which saw new states get into difficulties. Secondly, intellectuals created problems for themselves. They idealised too much, turned ideas into dogmas, and were dismissive of contrary views - 'the weight of history was on our side', and allowed their close proximity to power to distance themselves from new currents in intellectual thinking. In this way they were not able to provide fresh advice to new states.

- Why do intellectuals not want to speak out now? Three themes came through strongly. Firstly, the emotional and political attachment, in many cases of a lifetime, to the struggle. Secondly, a 'fear of falling' - of falling from the new political elite, and their often precarious position within this elite. And yet, finally, the new post-colonial states are in deep trouble and are in serious need of new ideas. So, thirdly, these intellectuals fear speaking out because of the 'politics of retribution' - as currently exemplified in the current behaviour of the ANC.

- What are the relevant concepts for intellectuals and who can be considered an intellectual? Here debate concerned the integrity of concepts - such as Afrocentrism or Marxism, the 'hegemony of the West', and identity: 'revolutionary', 'radical', 'organic', 'grassroots', etc. There was much consensus, prompted by comments from the audience, that openness and inclusivity, in terms of both approaches and who intellectuals were, was preferred, as was a more global and open rather than an Africa-centric vision. From within the audience, there was a strong undercurrent of tiredness that the term intellectual is too closely associated with the 'humanities and social sciences', and with certain elements of Africanism - for example, 'Just because the light bulb wasn't invented in Africa doesn't mean we [Africans] have to live in the dark.' 
A final theme from the audience also had traction: why was the symposium perpetuating the dominance of black political men, particularly in a symposium to discuss crisis: why was there no real gendered understanding of these issues in terms of crisis, cause and resolution? In press comment subsequent to the symposium, some participants expressed concern over tensions within their identities as 'black' 'radical' 'intellectuals' as a result of the behaviour of the state to which they had so much affinity, and the charges, all too often valid, against such black governmental competence and even legitimacy.
Internationally, the status of intellectuals, primarily but not exclusively public intellectuals, in politics is a long-standing theme in academic, political and public policy discussions and writing. Significantly, there are now increasing calls for intellectuals to play a more high-profile role in South Africa's public culture. The discussion trends in this symposium reaffirm these same wider calls. If the comments in this symposium are taken up, South African public culture can only become richer. 